\title{
Perceptions of Students and Teachers towards the Semester System of Tribhuvan University
}

\author{
Abatar Subedi \\ Lecturer \\ Central Department of Education (Mathematics) \\ Tribhuvan University, Kathmandu, Nepal \\ Email: abatar.subedi@tucded.edu.np
}

\begin{abstract}
This paper intents to analyze perceptions of students and teachers towards the semester system of Tribhuvan University (TU). The result of the study is based on the data collected through survey questionnaire from 40 university teachers and 194 master level students. The perception is discussed in terms of learning environment, resources, use of ICT tools, contents and activities. The findings show that the perception of teachers and students towards curriculum, teaching/learning environment, and regularity of classes and viability of semester system are in positive direction. However, the availability of learning resources and use of ICT tools in day to day teaching/learning are not in satisfactory way in the perception of the participants. Their perceptions also reveal that facilities of extra-curricular activities, play grounds and canteen are inadequate. Similarly, the teachers and students perceive that availability of both human and academic resources is inadequate. The students experience show that there is teacher domination in selection of teaching methods; less use of ICT materials to promote learning; difficulty in completing courses in the stipulated time and not timely declaring exam result. However, this system has encouraged and empowered creativity among students for learning.
\end{abstract}

Keywords: Semester system, perception, curriculum, learning environment, feedback, viability

\section{Introduction}

Semester system is one of the widely accepted education systems at higher education. Pathak and Rahman (2013) argued that the main motto of semester system is "to focus on continuous assessment system and regular monitoring students' progress, setting comprehensive and indepth learning environment to build capacity of learners by developing required knowledge, skills and attitudes to become an efficient and effective citizen diversified (p.84)". In Nepal, Tribhuvan University (TU) is one of the oldest and largest universities which have been providing higher education from its establishment at 2016 BS. Initially, the pedagogy of university was in yearly mode of education system. However, TU has recently begun to implement semester system of education at master degree for all subjects. It was initially started in 2070 BS in all the departments of University Campus, Kirtipur and now it has implemented in all constituents 
and affiliated campuses at the same level of higher education. There is the provision of internal assessment system in continuous basis to evaluate students' progress by concerned departments or campuses. This internal evaluation in semester covers forty percent marks and rest of the part is of external examination. The external exam is conducted by concerned dean offices of TU. In yearly/annual system of education, the evaluation of students was made at the end of academic year by written examination. It was a burden to the students as it leads them to the memorization of knowledge for one year and they had to completely rely on final test. Students had to wait for a long to get their results. So, avoiding burdens and mitigating the pain of delayed results with proper management to provide quality education was a big question among the stakeholders before practicing semester system. Such a question triggered the academicians, teachers and students attention towards the newly implemented semester system of TU.

Teachers and students are the major stakeholders and beneficiaries in implementing semester system. Pathak and Rahman (2013) believed that the effective implementation of any system depends to a large extent upon the satisfaction level of the beneficiaries (p.88). It means the measurement of satisfaction level of teachers and students is one of the indicators of effectiveness of semester system. Similarly, Jadoon, Jabeen and Zeba (2012) explained that the effective and successful implementation of semester system depends upon number of conditions including: well designed curriculum, content coverage within stipulated time, regularity of classes, timely and constructively feedback to students by the teachers, accessibility of teachers to students outside the class, availability of learning resources such as text books, reference books and computer facility, use of ICT in teaching/learning activities, highest level of secrecy and confidentiality in examination, transparency in evaluation and grade, and timely declaration of semester results (as cited in Pathak and Rahman, 2013, p.84).

TU started the semester system at master degree with scale down the yearly time period into two periods, each of 6 month called one semester. Altogether, the two years yearly program has been changed into 4 semesters. Similarly, TU revised the yearly courses into credit basis where the primary goal was to improve the quality of students' academic experience and to increase their educational gain. Chongbang (2014) argued that the yearly and semester systems of TU are difference more in practice rather than in their policy. The way students' perceive their teachers' in terms of knowledge of contents, communication ability, teaching methods and classroom management skills has significant relationship with students attitudes towards mathematics (Etunk et al., 2013), the necessity of developing strategies by all the stakeholders to arrange for minimum resources and facilities which have a direct bearing on student achievement (Pathak \& Rahman, 2013). Similarly, students achieve good marks in semester examination than that of annual system because their engagement is more on learning activities which develop positive attitudes about whole system (Yousaf et al., 2012).

However, Shoukat and Muhammad (2015) pointed that the politics among teachers and staff, lack of training and resources in semester system influence its success. In the same way, Singh and Kumar (2016) explained the challenges related to overall policies, management system, economical and environmental in implementation of semester system and thus it is necessary to develop proper policies timely by the university to overcome these challenges. Teachers and 
students perception towards semester system can have significant meaning to bring improvements in semester system. In this sense, how teachers and students perceive the semester system has become the interest of the study. The effectiveness and success of a program can be measured out of the perceptions of the concerned people. So, the study focuses on the analysis of the provisions and practices of semester system which ultimately could contribute the new knowledge about the semester system and would recommend the future policies for the viability of semester system in TU.

\section{Objectives}

The purpose of this study was to examine the ways that the students and teachers perceive semester system in terms of: curriculum, content coverage and regularity of classes, availability of learning resources and use of ICT, teaching/ learning environment, internal evaluation with feedback, final examination system, and the viability of it.

\section{Methodology}

The descriptive survey research design was adopted to conduct this research. The sample consisted to 40 teachers and 194 students, selected by using stratified random sampling representing the four faculties of TU including: Education, Humanity, management and science, from the population of graduate level teachers and students of central departments of University Campus at Kirtipur. Ten teachers and 50 students were selected from each stratum, but only 44 students were counted for the faculty of science at the end. The structured questionnaire developed by Pathak and Rahman (2013) was used as the tool to elicit the data which was adapted after revalidation with some modification in our context. There were six sub-sections in the questionnaire that incorporated the areas like curriculum, content coverage and regularity of classes, availability of learning resources and use of ICT in teaching, Teaching/learning environment of classroom, evaluation system with feedback, and viability of semester system in the questionnaire for both teachers and students, and one additional category that is teacher and teaching method was included in the questionnaire given to the students. The questionnaire was in Likert's type scale, consisted the statements (only positive) with five alternatives: strongly satisfied (SS), satisfied (S), uncertain (U), dissatisfied (D) and strongly dissatisfied (SD) which were ranked from 5, 4, 3, 2 and 1 respectively. The questionnaire also included the statements with three alternatives: yes, no comment and no (or adequate, not sure and inadequate) that were ranked from 5, 3 and 1 respectively. The collected data were analyzed by using descriptive statistics such as frequency, percentage, mean (M) and standard deviation (Sd), and then the results were interpreted under separate headings coined from the objectives of the study. The perception is assumed in positive direction if the mean perception score is greater than 3 , and in negative direction if it is less than 3 .

\section{Results and Discussions}

The results were presented and discussed as follows under the separate headings developed from the objectives of the study.

\section{Curriculum}

Designing an effective curriculum to achieve the intended outcomes of the higher education is pre-requisite of an effective semester system. The five questions about the curriculum representing the general concepts such as relevancy with present needs, flexibility, and amount 
of co-curricular activities, provision for project works, field study, tutorials, seminars, and the distribution of curriculum in the semester system were included to measure the perception of teachers and students towards the curriculum of semester system of TU. The representative data are presented in the table below:

Table 1:Teachers' and Students' Perception towards Curriculum

\begin{tabular}{|c|c|c|c|c|c|c|c|c|c|c|c|c|c|c|}
\hline \multirow[b]{2}{*}{ Items } & \multicolumn{7}{|c|}{ Teachers' Responses (in \%) $(\mathrm{N}=40)$} & \multicolumn{7}{|c|}{ Students' Responses (in \% ) $(\mathrm{N}=194)$} \\
\hline & SS & $\mathrm{S}$ & $\mathrm{U}$ & $\mathrm{D}$ & SDS & M & $\mathrm{Sd}$ & $\mathrm{SS}$ & $\mathrm{S}$ & $\mathrm{U}$ & $\mathrm{D}$ & $\begin{array}{l}\text { SD } \\
\text { S }\end{array}$ & M & $\mathrm{Sd}$ \\
\hline $\begin{array}{l}\text { There is a relevance } \\
\text { of curriculum with } \\
\text { the present needs }\end{array}$ & 00 & 85 & 7.5 & 7.5 & 00 & 3.78 & .58 & 3.6 & 50 & 14.9 & 22.7 & 8.8 & 3.17 & 1.1 \\
\hline $\begin{array}{l}\text { There is a flexibility } \\
\text { in curriculum }\end{array}$ & 5.0 & 47.5 & 12.5 & 30 & 5.0 & 3.18 & 1.08 & 7.7 & 35.6 & 25.8 & 23.7 & 7.2 & 3.13 & 1.08 \\
\hline $\begin{array}{l}\text { There are sufficient } \\
\text { co-curricular } \\
\text { activities included in } \\
\text { the curriculum }\end{array}$ & 7.5 & 35 & 25 & 27.5 & 5.0 & 3.13 & 1.06 & 3.6 & 24.2 & 20.1 & 37.6 & 14.4 & 2.65 & 1.11 \\
\hline $\begin{array}{l}\text { There is a provision } \\
\text { for project work, } \\
\text { field study, tutorial, } \\
\text { seminars in the } \\
\text { curriculum }\end{array}$ & 15 & 62.5 & 12.5 & 7.5 & 2.5 & 3.8 & .88 & 11.9 & 34.5 & 18.6 & 24.2 & 10.1 & 3.12 & 1.22 \\
\hline $\begin{array}{l}\text { There is an equal } \\
\text { distribution of } \\
\text { curriculum in each } \\
\text { semester }\end{array}$ & 15 & 65 & 10 & 10 & 0.0 & 3.85 & 0.80 & 5.2 & 38.7 & 22.2 & 24.2 & 9.8 & 3.05 & 1.11 \\
\hline
\end{tabular}

The results in Table 1 show that the overall perceptions of both the teachers and students towards the curriculum of semester system of TU are good. The mean of perception scores of teachers and students are 3.55 and 3.02, respectively. However, the students perceived that there are not sufficient co-curricular activities included in the curriculum. The mean of the perception score 2.65 of students in the table proves it.

The majority of both teachers and students accepted that the semester curriculum of TU is relevant with the present needs. The mean scores 3.78 and 3.17 of teachers and students respectively prove that they have positive perception. Similarly, the majority of the teachers and students accepted the flexibility of curriculum in semester system of TU. The mean of perception score of teachers is 3.18 and that of students is 3.13 on that item.

However, there is vast difference between the perception of teachers and students regarding the item there are sufficient co-curricular activities included in the curriculum. The mean score 3.13 of teacher shows the positive perception. In contrast, the mean score 2.65 of students shows the negative perception on that item. Similarly, the majority of both the teachers and students are satisfied with the provision for project work, field study, tutorial, and seminars in the curriculum 
of semester system. The mean of perception scores 3.80 and 3.12 of teachers and students on this item prove that both of them have positive perceptions.

Similarly, the large percentage of teachers and the students are satisfied with the equal distribution of curriculum in each semester of TU as shown in the table-1. The mean of perception score of both of them greater than three shows that they have positive perception on that item.

On the basis of data displayed in table above, it can be concluded that the teachers and students have positive perception towards the implemented curriculum of semester system of TU. Their perceptions could be supporting for the proper implementation of curriculum and curricular activities in semester system in higher education.

\section{Content Coverage and Regularity of Classes}

Content coverage and regularity of classes are closely tied together. Here, content coverage means to the completion of whole syllabus of the courses in the stipulated time of the semester. The course duration is provided in credit base system. There are 48 teaching hours for each three credit course. The classes should be regular to finish the course contents according to the academic calendar of semester system. The duration for completing the co-curricular activities needs to be sufficient for students and teachers. The data related to this concern are presented in following table:

Table 2: Perception towards Content Coverage and Regularity of Classes

\begin{tabular}{|c|c|c|c|c|c|c|c|c|c|c|c|c|c|c|}
\hline \multirow{2}{*}{ Items } & \multicolumn{7}{|c|}{ Teachers' Responses (in \%) $(\mathrm{N}=40)$} & \multicolumn{7}{|c|}{$\begin{array}{l}\text { Students' Responses (in \% ) } \\
(\mathrm{N}=194)\end{array}$} \\
\hline & SS & $\mathrm{S}$ & $\mathrm{U}$ & $\mathrm{D}$ & $\begin{array}{l}\text { SD } \\
\text { S }\end{array}$ & M & $\mathrm{Sd}$ & SS & $\mathrm{S}$ & $\mathrm{U}$ & $\mathrm{D}$ & $\begin{array}{c}\text { SD } \\
\text { S }\end{array}$ & M & $\mathrm{Sd}$ \\
\hline $\begin{array}{l}\text { The course contents are } \\
\text { covered within stipulated } \\
\text { time }\end{array}$ & 27.5 & 52.5 & 10 & 10 & 00 & 3.98 & .89 & 8.8 & 25.8 & 16 & 30.9 & 18.6 & 2.7 & 1.2 \\
\hline $\begin{array}{l}\text { Classes are regular in each } \\
\text { semester }\end{array}$ & 57.5 & 37.5 & 2.5 & 00 & 2.5 & 4.48 & .78 & 13.4 & 43.8 & 19.6 & 21.1 & 2.1 & 3.4 & 1.0 \\
\hline $\begin{array}{l}\text { There is enough time to the } \\
\text { students for completing co- } \\
\text { curricular activities }\end{array}$ & 05 & 42.5 & 32.5 & 15 & 05 & 3.28 & .96 & 4.1 & 18.6 & 22.7 & 40.2 & 14.4 & 2.5 & 1.0 \\
\hline
\end{tabular}

Table-2 shows that the teachers' perception towards the content coverage and regularity of the classes in the semester system is in positive direction where the overall mean of perception score is 3.91. But the overall mean of perception score 2.87 of students in this domain shows the negative direction. It means that the students did not perceive positively to the content coverage and regularity of classes of TU.

The results in the table -2 depict that teachers and students have opposite perception on the completion of course contents within stipulated time. The majority of teachers accepted the item with mean of perception score 3.98 while the large number of students rejected with mean of perception score 2.7. Similarly, the teachers have opposite perception on the item; there is enough 
time to the students for completing co-curricular activities. The mean of perception score 3.28 is an evidence of it. However, the students are not in favor of this which becomes explicit with the mean score 2.5 in the table above. On the other hand, both the majority of teachers and students accepted that classes are regular in each semester of TU. The mean of perception score on the item of teachers and students are 4.48 and 3.40 , respectively.

Hence, there is regularity of classes in the semester system of TU, although the course content is quite difficult to complete on time. Similarly, there is not sufficient time for the students to complete co-curricular activities as they perceived and experienced. However, both teachers and students have to finish the course content within limited time frame of semester system of TU.

\section{Teaching/ Learning Environment}

Providing interactive teaching/learning environment for the students is the characteristic of an effective semester system. The physical and academic environment of the campuses are basic for teaching and learning. The physical environment of classrooms such as good arrangement of desks, benches (like round table setting), black/white board, well-ventilation, sufficient space for the moving, arrangement of ICT facilities like projector, internet ,etc.are the minimum requirement for teaching and learning. In addition, the good academic environment demands the discussion, interaction and collaboration between teachers and students as in business together with the motivation, encouragement for teaching and learning in the classroom. There should not be any political obstacles during teaching/learning period. The departments, teachers and students should focus at least on authentic text books (recommended in curriculum) while teaching and learning in the classrooms together with related journals, reference books, monograph and other supportive academic materials and resources. The teachers and students perception towards teaching-learning environment is presented in the table below:

Table 3: Perception towards Teaching/ Learning Environment

\begin{tabular}{|c|c|c|c|c|c|c|c|c|c|c|c|c|c|c|}
\hline \multirow{2}{*}{ Items } & \multicolumn{7}{|c|}{ Teachers' Responses (in \%) $(\mathrm{N}=40)$} & \multicolumn{7}{|c|}{$\begin{array}{l}\text { Students' Responses (in \% ) }(\mathrm{N}= \\
194)\end{array}$} \\
\hline & SS & $\mathrm{S}$ & $\mathrm{U}$ & $\mathrm{D}$ & $\begin{array}{c}\text { SD } \\
\text { S }\end{array}$ & M & $\mathrm{Sd}$ & SS & $\mathrm{S}$ & $\mathrm{U}$ & $\mathrm{D}$ & $\begin{array}{c}\mathrm{SD} \\
\mathrm{S}\end{array}$ & M & $\mathrm{Sd}$ \\
\hline $\begin{array}{l}\text { There is a supportive } \\
\text { classroom (physical/ } \\
\text { academic) environment for } \\
\text { teaching and learning }\end{array}$ & 10 & 65 & 7.5 & 7.5 & 10 & 3.58 & 1.1 & 5.7 & 43.3 & 18.6 & 25.8 & 6.7 & 3.1 & 1.1 \\
\hline $\begin{array}{l}\text { There is not political } \\
\text { obstacle during teaching } \\
\text { and learning period }\end{array}$ & 17.5 & 42.5 & 27.5 & 12.5 & 00 & 3.65 & .92 & 23.7 & 36.6 & 15.5 & 16.5 & 7.7 & 3.5 & 1.2 \\
\hline $\begin{array}{l}\text { There is a focus on } \\
\text { motivation for teaching and } \\
\text { learning }\end{array}$ & 7.5 & 55 & 20 & 15 & 2.5 & 3.5 & .93 & 10.3 & 56.7 & 17 & 14.9 & 01 & 3.6 & .90 \\
\hline $\begin{array}{l}\text { There is always a } \\
\text { collaboration between } \\
\text { teachers and students for } \\
\text { learning }\end{array}$ & 15 & 50 & 27.5 & 5.0 & 2.5 & 3.7 & .88 & 14.4 & 50 & 24.7 & 9.3 & 1.5 & 3.6 & .89 \\
\hline $\begin{array}{l}\text { There is an encouragement } \\
\text { to use textbooks }\end{array}$ & 15 & 62.5 & 15.0 & 5.0 & 2.5 & 3.83 & .84 & 22.7 & 56.2 & 12.4 & 7.2 & 1.5 & 3.9 & .88 \\
\hline $\begin{array}{l}\text { There are spacious } \\
\text { classrooms for teaching and } \\
\text { learning }\end{array}$ & 7.5 & 62.5 & 17.5 & 7.5 & 5.0 & 3.6 & .93 & 7.7 & 41.2 & 21.6 & 21.6 & 7.7 & 3.2 & 1.1 \\
\hline
\end{tabular}


The data on theTable-3 reveals the positive perception of the teachers and students. The mean perception greater than 3 in each item is the evidence of it. As considering for the item, there is a supportive classroom (physical/ academic) environment for teaching and learning, that the majority of teachers and students showed their satisfaction with their mean of perception score 3.58 and 3.1 respectively. Likewise, the majority of them responded in supporting the item, there is not political obstacle during teaching and learning period. The mean scores 3.65 of teachers and 3.5 of students' show that there are political obstacles during teaching/learning period which are discouraging to them. Motivation in teaching and learning for both teachers and students is an important aspect of an effective semester system. The mean of perception scores 3.5 and 3.6 of teachers and students respectively reflect their positive perception on the item that semester system has focus on motivation for teaching and learning.

Similarly, the majority of teachers and students accepted that there is always collaboration between teachers and students for learning. The mean of perception scores on this item are greater than three. Using authentic text books in teaching and learning is another significant aspect of semester system. Table- 3 exhibits that the greater percentage of teachers and students favored and encouraged to use authentic textbook for teaching and learning.

Likewise, moving around the classroom to interact and to response individual student's problems, difficulties and encouraging them to achieve the objective of the teaching is basic characteristic of the good teacher in the semester system. For these activities, the classroom needs to be spacious and comfortable. Both the majority of teachers and students supported on the statement there are spacious classrooms for teaching and learning. Their mean scores are greater than three which show the positive perception on this item.

From the above discussion, it can be concluded that there is supportive physical and academic environment for teaching and learning in the semester system of TU in the experience of both the teachers and students.

\section{Teachers and Teaching Methods}

Teacher is the responsible person to implement the curriculum of semester system. Thus, the success of semester mainly depends upon the skillful teachers with sufficient content knowledge, their regularity and punctuality, teaching methods they employ and ability to use teaching audio visual materials such as ICT tools. In addition to these, teachers ' attitudes and their professional duties such as the accessibility inside and outside of the classrooms and their interactive behavior with students may affect the students learning which ultimately influence the overall succession of semester system. The following table presents the students' perception in this concern: 
Table 4 :Students' Perception towards Teachers and Teaching Methods

\begin{tabular}{|l|l|l|l|l|c|c|c|}
\hline \multirow{2}{*}{ Items } & \multicolumn{5}{|l}{ Students' Responses (in \% ) (N=194) } \\
\cline { 2 - 9 } & $\mathrm{SS}$ & $\mathrm{S}$ & $\mathrm{U}$ & $\mathrm{D}$ & $\begin{array}{c}\mathrm{SD} \\
\mathrm{S}\end{array}$ & $\mathrm{M}$ & $\mathrm{Sd}$ \\
\hline $\begin{array}{l}\text { There are skillful teachers } \\
\text { with sufficient domain/contents } \\
\text { knowledge }\end{array}$ & 17.5 & 53.1 & 13.9 & 11.3 & 4.1 & 3.6 & 1.02 \\
\hline $\begin{array}{l}\text { There is the regularity and } \\
\text { punctuality of the teachers }\end{array}$ & 9.3 & 46.9 & 23.2 & 16.5 & 4.1 & 3.41 & 1.00 \\
\hline $\begin{array}{l}\text { There is the positive attitude of } \\
\text { teachers towards students }\end{array}$ & 18 & 53.6 & 15.5 & 9.8 & 3.1 & 3.74 & .97 \\
\hline $\begin{array}{l}\text { There is an accessibility of teachers } \\
\text { outside the classes }\end{array}$ & 6.7 & 36.6 & 32 & 19.1 & 5.7 & 3.20 & 1.00 \\
\hline $\begin{array}{l}\text { There are the teaching methods } \\
\text { selected according to students needs }\end{array}$ & 2.1 & 24.2 & 30.4 & 30.9 & 12.4 & 2.73 & 1.02 \\
\hline $\begin{array}{l}\text { There is an interactive behavior } \\
\text { of the teachers focusing students } \\
\text { learning }\end{array}$ & 7.7 & 51.5 & 22.7 & 15.5 & 2.6 & 3.46 & .934 \\
\hline $\begin{array}{l}\text { There are Audio visual aids used } \\
\text { together with ICT to promote } \\
\text { student learning }\end{array}$ & 7.2 & 32.5 & 21.6 & 23.2 & 15.5 & 2.93 & 1.21 \\
\hline
\end{tabular}

The data displayed in the table -4 shows that the overall perception of the students towards their teachers and teaching method in semester system is positive. It is supported by the greatest mean 3.74. This implies that the TU teachers show their caring attitudes towards their students in learning in semester system. However, the teaching methods as adopted by teachers are not according to students needs as it is indicated by students' of perception score 2.73. The least perception score shows students dissatisfaction towards the teaching methods used in semester system.

Similarly, a good majority of the students positively perceived that there are skillful teachers with sufficient domain/contents knowledge; however, a few of them have some reservation while accepting the statement. The mean score 3.6 proves the positive perception to the item. Likewise, a good majority of the students have positive attitude towards the regularity and punctuality of the teacher in semester system with mean of perception score 3.41. However some of them could not decide on this item.

In the same way, many of the students accepted that they get positive response and caring behavior of the teacher. The data in the table- 4 shows that the students are satisfied the way that 
their teachers care and behave them. The mean score 3.74 proves their satisfaction. Regarding the statement there is an accessibility of teachers outside the classes, many of the students present themselves as positive, however some of them are uncertain. The mean score 3.20 shows the positive perception to the item.

Selection of teaching methods according to students' needs and demands is an important characteristic of the teachers in the semester system of higher education. But the result shows that the majority of the students show their dissatisfaction towards it. The mean score 2.73 proves their negative perception to the choice of teaching methods according to their needs. This evidence shows that teachers themselves select their own teaching methods according to the nature of contents in the semester system of TU.

The result of the students' responses towards the item" there is an interactive behavior of the teachers focusing students learning" in the table -4 shows that the majority of students are in acceptance to the item. The mean score 3.46 on that item is an evidence of the fact that TU teachers have interactive behaviors in the semester system.

Using audio visual materials together with ICT to promote student learning in semester system is an important part of instruction to refine students understanding of the concepts. But, the result in the table-4 shows the negative perception because the mean score in this regard is only 2.93 . This proves that the teachers did not make use of sufficient audio visual aids and ICT materials in their teaching.

From the overall discussion, it can be concluded that the students are satisfied towards the teachers and their teaching methods. The overall mean perception score 3.30 is a good evidence of their satisfaction.

\section{Evaluation and Feedback}

Continuous and comprehensive evaluation system is one of the basic characteristics of the semester system. It includes examination of academic and non-academic achievement in all dimension of personality of students. The process of evaluation must be transparent and comprehensible for all the stakeholders including the students, teachers and parents. The following table shows the teachers' and students' perception towards the overall evaluation and feedback provided in the semester system of TU. 
Table 5: Perception towards Evaluation System and Feedback

\begin{tabular}{|c|c|c|c|c|c|c|c|c|c|c|}
\hline \multirow{2}{*}{ Items } & \multicolumn{5}{|c|}{ Teachers' Responses (in \%) $(\mathrm{N}=40)$} & \multicolumn{5}{|c|}{ Students' Responses (in \% $)(\mathrm{N}=194)$} \\
\hline & Y & $\mathrm{NC}$ & $\mathrm{N}$ & M & $\mathrm{Sd}$ & $\mathrm{Y}$ & $\mathrm{NC}$ & $\mathrm{N}$ & M & $\mathrm{Sd}$ \\
\hline $\begin{array}{l}\text { You understand and satisfy } \\
\text { with the CGPA system }\end{array}$ & 70 & 10 & 20 & 4.00 & 1.63 & 50.5 & 16 & 33.5 & 3.34 & 1.81 \\
\hline $\begin{array}{l}\text { You believe that grading } \\
\text { system reduces subjective } \\
\text { biasness in evaluation }\end{array}$ & 70 & 7.5 & 22.5 & 3.95 & 1.69 & 54.2 & 7.7 & 38.1 & 3.32 & 1.89 \\
\hline $\begin{array}{l}\text { You believe that internal } \\
\text { assessment and overall } \\
\text { evaluation is transparent }\end{array}$ & 62.5 & 15 & 22.5 & 3.80 & 1.68 & 41.2 & 7.8 & 51 & 2.80 & 1.92 \\
\hline $\begin{array}{l}\text { You believe that results } \\
\text { are declared in time. }\end{array}$ & 32.5 & 15 & 52.5 & 2.60 & 1.82 & 16.5 & 0.5 & 83 & 1.67 & 1.49 \\
\hline $\begin{array}{l}\text { Teachers show scripts } \\
\text { of examination, and } \\
\text { assignments regularly }\end{array}$ & 75 & 12.5 & 12.5 & 4.25 & 1.41 & 40.7 & 9.8 & 49.5 & 2.82 & 1.90 \\
\hline $\begin{array}{l}\text { Teacher (or students) } \\
\text { provide (or get) } \\
\text { constructive feedback } \\
\text { to students (or from } \\
\text { teachers) }\end{array}$ & 95 & 00 & 05 & 4.80 & 0.88 & 52.6 & 10.8 & 36.6 & 3.32 & 1.87 \\
\hline $\begin{array}{l}\text { You become creative than } \\
\text { examination oriented }\end{array}$ & - & - & - & - & - & 56.2 & 5.2 & 38.6 & 3.35 & 1.92 \\
\hline $\begin{array}{l}\text { Frequent examinations do } \\
\text { not create anxiety among } \\
\text { the students }\end{array}$ & 60 & 15 & 25 & 3.70 & 1.72 & 51 & 13.4 & 35.6 & 3.31 & 1.84 \\
\hline $\begin{array}{l}\text { Frequent examinations do } \\
\text { not create difficulties to } \\
\text { manage among teachers }\end{array}$ & 40 & 15 & 45 & 2.90 & 1.87 & - & - & - & - & - \\
\hline $\begin{array}{l}\text { Political pressure of } \\
\text { students union do } \\
\text { not create difficulties } \\
\text { to manage internal } \\
\text { evaluation }\end{array}$ & 67.5 & 10 & 22.5 & 3.90 & 1.69 & - & - & - & - & - \\
\hline $\begin{array}{l}\text { Teachers regular monitor } \\
\text { students by using } \\
\text { alternative techniques of } \\
\text { evaluation except paper } \\
\text { pencil test }\end{array}$ & 62.5 & 22.5 & 15 & 3.95 & 1.50 & 34.5 & 9.3 & 56.2 & 2.57 & 1.86 \\
\hline
\end{tabular}

Note: $\mathrm{Y}=$ Yes, $\mathrm{N}=\mathrm{No}, \mathrm{NC}=$ No Comment

The data on Table-5 display the overall perception of teachers' towards the evaluation and feedback in semester system of TU. Teachers have positive perception with their mean score 
3.79. However, the students are not fully satisfied to the item as their mean of perception score is 2.94 .

This sub-section includes 10 items for teachers and only nine items for students. The data shows that the majority of teachers, i.e. $70 \%$ and students $50.5 \%$ accepted that they understood and satisfied with the CGPA system of semester. Their mean of perception scores are 4.0 and 3.34, respectively, on that item show the positive perception. Similarly, they believed that grading system reduces the biasness in evaluation. However, the majority of teachers believed on transparency of internal and overall evaluation system with mean perception score 3.80.In contrast, the majority of students did not believe on the transparency of evaluation at there. Their mean score 2.80 is the evidence of negative perception towards CGPA system. Likewise, the majority of teachers and students have contrasting views on the item that teachers provide scores of assignments regularly in the semester class of TU.

However, the majority of teachers and students disagreed to the way their result is published. They experience the untimely result. The mean of perception scores of teachers and students 2.60 and 1.67 prove this fact. From their mean score, I come to conclude that the semester system of TU is still affected from the delayed result of examination.

Providing regular and constructive feedback on the performance of the students is one of the mottos of semester system, which helps students to correct/improve their performance level in higher education. The result given in Table-5 shows that almost all the teachers agree with the item you provide constructive feedback to students. The mean score on this item is 4.80 . In contrast, only $52.6 \%$ students are agreed with this item.

In the same way, the majority of students reported that they become creative and attentive without being examination-oriented. The mean score 3.35 supports that students are encouraging to become creative than being examination oriented in the semester system. Similarly, the highest percent of teachers and students accepted that frequent examinations do not create anxiety among students. The mean of perception scores of teachers and students on this item are 3.70 and 3.31 respectively. So, it proves that both of them perceived frequent monitoring and examination positively. However, the majority of teachers perceived that frequent examination creates difficulties among them. It means frequent examination is difficult tasks for the teachers in semester system, however, it plays vital role to find students' performance and to provide timely feedback for the improvement.

TU has the provision of students union in every constituent campus which sometime influences the internal evaluation system of students in higher education. In total $67.5 \%$ teachers are agreed to the statement, political pressures of students union do not create difficulties to manage internal evaluation. Their mean score 3.90 is the evidence of their positive perception. In addition, the result on table -5 shows the contradictory views among teachers and students regarding the item: teachers regular monitor students by using alternative techniques of evaluation except paper pencil test. The majority of teachers agreed it with mean score 3.95 and the majority of students 
disagreed it with mean perception 2.57. Whatever the score is, teachers in semester try their best to use continuous assessment for the internal evaluation.

The overall discussion shows that the teachers have at least positive perception to implement continuous evaluation and feedback system in semester. However, the students have raised the questions of ensuring transparency, regular assignment and practice of alternative evaluation in semester system of TU.

\section{Learning Resources and Use of ICT}

Availability of learning resources and use of information communication technology (ICT) in teaching and learning are inevitable for an effective practice of semester system. Learning resources can be classified generally into three categories viz. physical resources, human resources and the resources related to Information Communication Technology (ICT). The following table shows the teachers' and students perception towards the availability of learning resources and use of ICT in semester system of TU.

Table 6: Perception towards Learning Resources and Use of ICT

\begin{tabular}{|c|c|c|c|c|c|c|c|c|c|c|}
\hline \multirow[t]{2}{*}{ Items } & \multicolumn{5}{|c|}{$\begin{array}{l}\text { Teachers' Responses (in \%) } \\
(\mathrm{N}=40)\end{array}$} & \multicolumn{5}{|c|}{$\begin{array}{l}\text { Students' Responses (in \% ) } \\
(\mathrm{N}=194)\end{array}$} \\
\hline & A & NS & I & M & $\mathrm{Sd}$ & A & NS & I & M & $\mathrm{Sd}$ \\
\hline Availability of classroom for all subjects & 50 & 05 & 45 & 3.10 & 1.97 & 53.1 & 7.2 & 39.7 & 3.27 & 1.91 \\
\hline $\begin{array}{l}\text { Number of desk bench and other furniture } \\
\text { in the classroom }\end{array}$ & 75 & 00 & 25 & 4.00 & 1.75 & 75.3 & 5.1 & 19.6 & 4.11 & 1.60 \\
\hline $\begin{array}{l}\text { Facility for other extra-curricular activities } \\
\& \text { play ground }\end{array}$ & 15 & 22.5 & 62.5 & 2.05 & 1.50 & 20.6 & 10.3 & 69.1 & 2.03 & 1.63 \\
\hline Number of teachers & 40 & 05 & 55 & 2.70 & 1.95 & 74.7 & 7.8 & 17.5 & 4.14 & 1.55 \\
\hline Number of administrative staffs & 52.5 & 05 & 42.5 & 3.20 & 1.96 & 59.8 & 13.4 & 26.8 & 3.66 & 1.75 \\
\hline $\begin{array}{l}\text { ICT and Audio visual aids in the } \\
\text { classroom }\end{array}$ & 42.5 & 7.5 & 50 & 2.85 & 1.94 & 30.9 & 8.3 & 60.8 & 2.40 & 1.83 \\
\hline Library and Reading room facilities & 35 & 7.5 & 57.5 & 2.55 & 1.89 & 47.4 & 6.2 & 46.4 & 3.02 & 1.94 \\
\hline $\begin{array}{l}\text { Availability of references and text books } \\
\text { in the library }\end{array}$ & 10 & 12.5 & 77.5 & 1.65 & 1.31 & 33 & 9.8 & 57.2 & 2.52 & 1.84 \\
\hline $\begin{array}{l}\text { Availability of Journals and Articles in } \\
\text { the library }\end{array}$ & 2.5 & 12.5 & 85 & 1.35 & 0.89 & 42.8 & 11.3 & 45.9 & 2.94 & 1.89 \\
\hline $\begin{array}{l}\text { Computer facilities for students and } \\
\text { teachers }\end{array}$ & 17.5 & 12.5 & 70 & 1.95 & 1.57 & 16.5 & 14.9 & 68.6 & 1.96 & 1.53 \\
\hline Access to internet facilities & 22.5 & 10 & 67.5 & 2.10 & 1.69 & 19.6 & 12.4 & 68 & 2.03 & 1.61 \\
\hline Availability of canteen & 27.5 & 12.5 & 60 & 2.35 & 1.78 & 51.5 & 6.7 & 41.8 & 3.20 & 1.93 \\
\hline
\end{tabular}

Note: $\mathrm{A}=$ Adequate, $\mathrm{I}=$ Inadequate, $\mathrm{NS}=$ Not Sure

The data displayed on Table-6 show that overall teachers and students are not fully satisfied the way learning resources and ICTs are in actual practice in semester system. The overall 
mean scores of teachers and students towards the availability of learning resources and use of ICT in semester system are 2.48 and 2.94. This result implies that both of them have negative perception.

Concerning to the items included in table -6 , the majority of teachers and students perceived the item, the availability of classroom for all subjects and number of desk benches and other furniture in classroom are adequate in the semester system of TU. The highest percentage of teachers, i.e. $75 \%$ and students, i.e. $75.3 \%$ agreed with the availability of adequate number of desk benches and other furniture in the classroom of semester system. The mean score of them on these items are also greater than three. In contrast, the majority of both teachers and students perceived that the "facility for other extra-curricular activities and playground" are inadequate in the semester system of TU. Their mean scores 2.05 and 2.03, respectively. It shows that teachers and students are not satisfied to the facilities for extracurricular activities. Likewise, the majority of teachers reported the lack of manpower for running the semester system.

Likewise, the data in the table -6 also shows that the majority of teachers and students accept that the administrative staffs are adequate in number. The mean score 3.20 of teachers' and 3.66 of students' can be taken as the proofs. Similarly, the results also show that the majority teachers and students accepted that there are inadequate facilities of ICT materials, audio-visual aids, availability of references, textbooks, journals, articles, and the facilities of computer as well as internet in the semester system of TU. The mean scores of all the items related to these facilities are also less than three. It helps to justify and support the inadequate facilities of these information resources in TU.

In the similar vein, the result shows that majority of teachers' perceived inadequate facility of library and reading room for teachers. However, majority of students $(47.4 \%)$ accepted the number is adequate. Likewise, the majority of students with mean perception score 3.20 shows that the availability of canteen for students is adequate. In the same way, the majority of teachers show acceptance to the item, 'the canteen facilities are inadequate in semester system of TU. The mean score 2.35 is a good example of inadequate physical facilities.

From the discussion above, it has become clear that that the availability of physical and human resources are satisfactory, however, the information resources are not adequate in the semester system in the perception of teachers and students.

\section{Viability (Future Existence) of Semester System}

TU has reintroduced semester system from 2070 BS at central departments for the students of Master's degree and then extended to its constituent and affiliated campuses recently at master level in all subjects. From the beginning, the academicians, educators, teachers, students and other stakeholders have raised several questions regarding the sustainability and viability of this system for a long future. In this regard, how the major stakeholder namely students and teachers perceive the viability of semester system has become another concern of this study. The data related to this very notion is given in the table below: 
Table 7: Perception towards Viability of Semester System

\begin{tabular}{|c|c|c|c|c|c|c|c|c|c|c|c|c|c|c|}
\hline \multirow{2}{*}{ Items } & \multicolumn{7}{|c|}{ Teachers' Responses (in \%) $(\mathrm{N}=40)$} & \multicolumn{7}{|c|}{$\begin{array}{l}\text { Students' Responses (in \% ) }(\mathrm{N}= \\
\text { 194) }\end{array}$} \\
\hline & SS & $\mathrm{S}$ & $\mathrm{U}$ & $\mathrm{D}$ & $\begin{array}{c}\text { SD } \\
\text { S }\end{array}$ & M & $\mathrm{Sd}$ & SS & $\mathrm{S}$ & $\mathrm{U}$ & $\mathrm{D}$ & $\begin{array}{c}\text { SD } \\
\text { S }\end{array}$ & M & $\mathrm{Sd}$ \\
\hline $\begin{array}{l}\text { Semester system is viable } \\
\text { for future in TU }\end{array}$ & 22.5 & 47.5 & 27.5 & 2.5 & 00 & 3.9 & .78 & 30.9 & 43.3 & 16 & 6.2 & 3.6 & 3.9 & 1.02 \\
\hline $\begin{array}{l}\text { Semester system is } \\
\text { necessary to implement in } \\
\text { all the constituent campuses } \\
\text { of TU at Master Level }\end{array}$ & 35 & 40 & 17.5 & 05 & 2.5 & 04 & .99 & 41.2 & 39.7 & 12.4 & 5.7 & 01 & 4.14 & .92 \\
\hline $\begin{array}{l}\text { Semester System is } \\
\text { considered very difficult to } \\
\text { manage in future }\end{array}$ & 20 & 32.5 & 25 & 17.5 & 05 & 3.45 & 1.15 & 14.9 & 25.3 & 26.8 & 24.2 & 8.8 & 3.13 & 1.2 \\
\hline
\end{tabular}

The data in Table 7 show the overall perceptions of teachers and students towards the viability of semester system. The mean score 3.78 and 3.72 respectively imply that both the teachers and students have strong belief on the viability of semester system. To be specific, the majority of teachers and students accepted the item: semester system is viable for future in $T U$ with their equal mean perceptions score 3.9. Similarly, the majority of teachers and students are in favor to implement this system to all constituent campuses of TU at master level. Their mean of perception score on the table -7 depicts that they have positive perception on this item. Likewise, the teachers and students perceived difficulties to practice semester system effectively for a long future. The mean of perception scores 3.45 and 3.13 of them is a good evidence of it.

In conclusion, it can be argued that though teachers and students have positive perception towards the viability of semester system in future, it is not out of question due to the difficulties in management and proper practice. Thus, the results imply that TU has to improve the present practice of semester system for its sustainability and viability for a long future.

\section{Conclusion}

The findings of this study reflect that there are several positive aspects of semester system as perceived by teachers and students. Still there are many things to be improved along with the practice of semester system throughout the nation. The provision of project works, field works, tutorials and seminars in the curriculum are the good aspects of semester system of TU. Similarly, the regularity of classes, supportive physical and academic environment, less political obstacles in evaluation system, collaboration in learning system, frequent monitoring the students' progress, focusing on creativity and providing constructive feedback are the good practices of the semester system despite the limited physical, human and information resources . However, problems in covering course content in the stipulated time, lack of sufficient co-curricular activities, teachers' domination in the selection of teaching method, limited time for co-curricular activities, lack of required human and information resources, and delay in result publication are the conditions yet to be improved. 
Moreover, for the quality enhancement and the viability of semester system of TU, improvement in management system is essential. The provision of ensuring transparency among students and teachers can reduce biasness in evaluation. The effective semester system should focus on student's presentation, viva and other practical works for academic excellence which in turn, could promote collaborative learning environment. Similarly, selection and application of autonomous activities for the students can help them increase the level of confidence as well as communication skills. Redefining semester system with an evaluation of its effectiveness can ultimately change the performance of both the students and teachers make them more active, creative and competent problem solvers. From the findings of the study, I come to conclude that still there are many rooms for the improvement in the management such as the application of academic calendar, publishing results on time, taking comprehensive internal evaluation, integration of ICT based resources like computer, internet, and other resources including text books, reference books, journals, articles, and so on. Some aspect of physical management such as sanitation, pure drinking water, and cafeteria are some other things to be taken into the consideration. Similarly, the curriculum of semester system of TU needs to assessed, revised and updated as per the need of academia. The system should not be taken as like the split of annual system in to two halves, rather there is a call for innovative practices. Thus, I would like to argue for the improvements in the present system of semester including the implications of research and the suggestions of well experienced professors to enhance the quality of higher education. Finally, research based instruction is the need of $21^{\text {st }}$ century's pedagogy, so dew attention should be given to the research oriented activities in order to support academic excellencies, devising policy and planning, and the viability and sustainability of semester system in higher education.

\section{References}

Chongbang, K.B. (2014).Comparative Study of Semester System and Annual System of Faculty of Education. A Mini- Research submitted to Dean Office, Tribhuvan University.

Etunk, E.N., Afangideh, M.E. \&Uya, A.O. (2013).Students perceptions of teacher characteristics and their attitudes towards mathematics in oron education zone, Nigeria.International Education Studies, 6 (2), 197 - 204.Canada: Canadian Centre of Science and Education. Retrieved from http://www.ccsenet.org/journal/index.php/ies/article/view/24303

Pathak, N. and Rahman A.(2013). Perception of students and teachers towards semester system: A study in some selected degree colleges of nagon town of nagon district of Assam. Journal of Education and Practices, 4 (1), 84- 91. Retrieved from https://pdfs. semanticscholar.org/77f6/180a05f45acc30be80c219af998788fecfa3.pdf

Shoukat, L. and Muhammad, W. (2015). Perception of teachers and students towards the functionality of semester system at university leval in the context of pakistani social and administrative set-ups. International Journal of Teaching and Education, 3(4), 68 80. Retrieved from http://ideas.repec.org/a/sek/jijote/v3y2015i4p68-80.html( Retrieve on Feb - , 27, 2017) 
Singh, B.K and Kumar, P. (2016). Challenges in implementation of semester system in globalized world. International Journal of Applied Research, 2(3), 89 - 91. Retrieved fromhttp:// $\mathrm{http}: / / \mathrm{www}$. allresearchjournal.com/archives/?year=2016\&vol=2\&issue=3\&part=B

Yousaf, A. and Hashim, M. (2012). A case study of annual and semester systems of examination on government college of management sciences, Peshawar, pakistan. International Journal of Academic Research in Business and Social Sciences, 2 (9), 53- 73. Retrieved from https://www.researchgate.net/publication/265751215_A_Case_study_of_Annual_ and_Semester_Systems_of_Examination_on_Government_College_of_Management_ Sciences_Peshawar_Pakistan 